\title{
The Effect of Population Behavior on New Renewable Energy in Primary Energy Mix for 2025 National Target: Sumedang Regency Review, West Java
}

\author{
Handoko, ${ }^{\mathrm{a}, *}$ Adianto, ${ }^{\mathrm{b}}$ and S.C. Loon, ${ }^{\mathrm{c}}$ \\ a) Mechanical Engineering Masters Student, Faculty of Industrial Technology, Trisakti University, Jakarta, Indonesia \\ b) Supervising Lecturer of Mechanical Engineering Students Master of Mechanical Engineering, Faculty of Industrial Technology, Trisakti \\ University, Jakarta, Indonesia; Lecturer in the Department of Mechanical Engineering, Tarumanegara University, Jakarta, Indonesia \\ c) School of Mechanical Engtineering, Universiti Teknologi Malaysia
}

*Corresponding author: handokomoekiran@ymail.com; handokomoekr@gmail.com

\section{Paper History}

Received: 15-August-2019

Received in revised form: 20-January-2020

Accepted: 30-March-2020

\section{ABSTRACT}

The results of the Study of the Agency for the Assessment and Application of Technology in 2018 estimated the primary energy mix target of renewable energy at 23 (twenty three) percent by 2025 will not be reached. It is estimated that only reach 12.9 (twelve point nine) percent. The use of renewable energy, especially biomass and biogas by the population independently has not been included in the calculation of meeting the energy mix target by the government. Even though the potential of primary energy of bio energy in Indonesia is 32,653.8 MW. This study examines the behavior of the population towards the use of renewable energy, especially biomass and biogas in meeting their needs for cooking and business. The face-to-face research was carried out on 85 (eighty-five) respondents and online as many as 16 (sixteen) respondents in 17 (seventeen) villages in 7 (seven) districts in Sumedang Regency. The study was also conducted on 574 (five hundred seventy four) respondents both online and face to face in 366 (three hundred sixty six) villages in 240 (two hundred forty) districts in 91 (ninety one) districts / cities in 22 (twenty two) provinces. From the results of research and analysis of characteristics, descriptive analysis, logistic analysis and calculations; shows that: (a) trends in 2025, Sumedang residents choose to use biogas fuel, (b) trends in 2025, Indonesians choose to use solid fuels, (c) minimum contribution or potential
\end{abstract}

contribution of Indonesian population to achieving energy mix targets primary New and Renewable Energy of 3.80 (three point eight) percent in 2018 and increased to 8.16 (eight point sixteen) percent in 2025 or about 35 (thirty five) percent of the target of the New and Renewable Energy mix. Thus, this research needs to be followed up and encourage the government through the National Energy Council to conduct more comprehensive research in all regions in Indonesia.

KEY WORDS: Primary Energy Mix, Biogas, Biomass, Renewable Energy, Population Behavior.

\section{NOMENCLATURE}

KEN Kebijakan Energi Nasional

RUEN Rencana Umum Energi Nasional

$R U E D$ Rencana Umum Energi Daerah

$B P P T$ Badan Pengkajian dan Penerapan Teknologi

OEI Outlook Energi Indonesia

NRE New and Renewable Energy

$R E \quad$ Renewable Energy

LTSHE Lampu Tenaga Surya Hemat Energi

$D M E \quad$ Desa Mandiri Energi

HTIE Hutan Tanaman Industri Energi

ESDM Energi dan Sumber Daya Mineral

$P L N \quad$ Perusahaan Listrik Negara

BPS Badan Pusat Statistik

\subsection{INTRODUCTION}


To achieve the goals of the Republic of Indonesia's National Energy Policy (KEN), the President established Presidential Regulation No. 22 of 2017 concerning the National Energy General Plan [1]. This regulation refers to Government Regulation No. 79 of 2014 concerning the National Energy Policy, where the KEN is prepared by the National Energy Board. KEN is a guideline for giving direction on national energy management in order to realize energy independence and national energy security to support sustainable national development. The National Energy General Plan (RUEN) is the central government policy at the macro level regarding national energy management plans. RUEN is a translation and plan for implementing a crosssectoral KEN. To achieve the target of KEN, a modeling of energy demand (supply-demand) was made until 2050. Policies and strategies to be carried out were determined. RUEN becomes a reference in preparing the Regional Energy General Plan (RUED) on a micro-scale. Government Regulation No. 79 of 2014 Article 9 stipulates energy needs in Indonesia until 2025 and 2050 by using the primary energy mix as shown in Table 1.1 below.

Table 1.1 Primary Energy Mix [2]

\begin{tabular}{|l|c|c|}
\hline Primary Energy & Until 2025 & Until 2050 \\
\hline New and Renewable & $23 \%(*)$ & $31 \%(*)$ \\
\hline Crude Oil & $25 \%$ & $20 \%$ \\
\hline Coal & $30 \%$ & $25 \%$ \\
\hline Natural Gas & $22 \%$ & $24 \%$ \\
\hline Total & $100 \%$ & $100 \%$ \\
\hline
\end{tabular}

Note: (*) As long as the economy is met.

In line with the goal of creating energy independence and energy security, the role of renewable energy is enhanced even greater. The government supports its fulfillment by using New and Renewable Energy in the implementation of primary energy mix in Indonesia [1,3]. The main concern in the development of electricity infrastructure projects is the use of renewable energy. In its journey, since the enactment of Government Regulation Number 79 Year 2014 with 2015, 2016 and 2017 RUEN, Agency for the Assessment and Application of Technology (BPPT)'s review in OEI 2018 states that the target of using renewable energy planned by the government will be difficult to achieve $[1,4,5,6]$. Table 1.2 shows the targets, achievements, projections of NRE achievement and BPPT study results.

Table 1.2: Achievement Target and Projection of NRE Achievement

\begin{tabular}{|c|c|c|c|c|c|}
\hline Year & $\begin{array}{c}\text { Target } \\
{[1]}\end{array}$ & $\begin{array}{c}\text { Achievement } \\
\& \text { Projection } \\
(*)[12,13]\end{array}$ & $\begin{array}{c}\text { Achievem } \\
\text { ent }[14]\end{array}$ & $\begin{array}{c}\text { Projection } \\
{[15]}\end{array}$ & $\begin{array}{c}\text { BPPT } \\
\text { OEI } \\
2018[2]\end{array}$ \\
\hline 2010 & & 4,42 & & & \\
\hline 2011 & & 4,32 & & & \\
\hline 2012 & & 4,52 & & & \\
\hline 2013 & & 5,18 & & & \\
\hline 2014 & & 6,35 & & & \\
\hline 2015 & 5,06 & 6,70 & & & \\
\hline 2016 & 5,69 & 7,70 & & & \\
\hline 2017 & 6,36 & 8,25 & 12,15 & & \\
\hline 2018 & 7,23 & 8,80 & 12,71 & 12,50 & \\
\hline 2019 & 8,21 & 9,35 & & 12,40 & \\
\hline 2020 & 9,60 & 9,90 & & 12,10 & 11,00 \\
\hline 2021 & & 10,45 & & 12,40 & \\
\hline
\end{tabular}

\begin{tabular}{|l|l|l|l|l|l|}
\hline 2022 & & 11,00 & & 12,60 & \\
\hline 2023 & & 11,55 & & 13,20 & \\
\hline 2024 & & 12,10 & & 14,10 & \\
\hline 2025 & & 12,65 & & 23,10 & 12,90 \\
\hline
\end{tabular}

Source: Processed from PerPres No. 22/2017, EBTKE Statistics 2016, 2 Presentations of ESDM, BPPT OEI 2018 [1,7,8,9,10,4] (*) Projections for 2017-2025 are calculated with an average growth of $0.55 \%$ (processed from $[7,8]$.

By paying attention to the availability of RE-based primary energy in Indonesia [1], the potential is varied and quite large. The primary energy available consists of geothermal, hydropower, mini hydro \& micro hydro, bioenergy, solar/ sunlight, wind and movement \& temperature differences in the sea layers. Overall in Indonesia there is potential RE with power equivalent to $420,029.4 \mathrm{MW}$ with total bioenergy equivalent to 32,654.4 MW.

The use of biomass and biogas by the population will contribute in achieving the target of using NRE in the primary energy mix. For this reason, it is necessary to conduct research on the significant impact of the influence of population behavior on the use of renewable energy (RE). The use of RE by the population in their daily lives is biomass and biogas. The achievement of the use of RE by the population independently does not require as much cost as is required in: (a) the use of B20 biodiesel and gradually increased the percentage of FAME (oil palm) to B100 [8,11], (b) access to lighting with energy-efficient solar lamps (LTSHE) [8]. The potential of RE in West Java is the most comprehensive and the largest in Indonesia, namely 28,235.1 MW including bioenergy at 2,554.1 MW [1]. Its area covers 27 regencies/cities [12].

Sumedang Regency was chosen for the following reasons:

a. It is estimated that some of the population uses primary energy

RE with the availability of fuel wood, rice husks, sawdust,

charcoal, biomass briquettes, dairy farming centers, beef cattle, buffaloes, horses, goats, sheep and poultry and tofu industry centers $[13,14,15,16,17,18,19,20,21,22]$;

b. The Sumedang Regional Government Strategy to increase energy independence and water sufficiency [23]; and

c. Policy targets for developing energy creation and utilization [23].

According to the 2017 West Java Provincial Housing Statistics, the use of fuel wood, charcoal and other solid fuels in rural areas is $27.20 \%$ and in cities is $4.32 \%$ with an average city and rural area of $11.17 \%[13,14]$. This percentage is categorized quite high [13]. Firewood users for cooking are still high in Indonesia. In 2017 in Indonesia, 31.3\% of rural people still cook using firewood. This figure is very different from urban people, which is only $5.15 \%$ [14]. Compared to 2012 data, there was a decline in firewood users. Users in the village were $58.79 \%$ and in the city $12.79 \%$ [14].

\subsection{Problem Formulation}

In this research, it will be observed the behavior of the population towards the use of renewable energy, especially biomass and biogas. The choice of population for various primary energy for household needs (cooking, heating water, etc.) and tofu craftsmen are analyzed. The extent of Sumedang's love for the tradition of using traditional fuels and his understanding of a clean and sustainable environment. 
Based on achievement data from 2010 to 2016 and assuming an increase in the growth of the NRE mix for electric and nonelectric power on average by $0.55 \%[13,14]$ or $6.1 \%$ / year according to the BPPT study [4], then in 2025 it is estimated that there will be a shortage of $10.35 \%$ or $10.1 \%$ according to a BPPT study (Table 1.2). The question is whether the utilization of RE as primary energy by the population independently can add a sufficient percentage in achieving the national target of non-fossil primary energy or NRE?

\subsection{Research Objectives}

The purpose of this study is to determine the type and amount of $\mathrm{RE}$ as primary energy use by the population by:

a. examine whether the behavior of the population in Sumedang Regency is still willing to use RE as primary energy in their daily lives until 2025;

b. calculate the percentage of the population of Sumedang Regency that uses biomass and biogas and compares it with statistical data for West Java; and

c. to study whether the results of research in Sumedang Regency can be used as a reference on a national scale.

\subsection{Research Benefits}

It is hoped that the research results can provide confirmation that: a. The use of biomass and biogas primary energy by the population independently can contribute solutions to achieve the national target of primary energy NRE in the primary energy mix by 2025 .

b. As proof of community participation in reducing greenhouse gas emissions reductions.

c. As a reference for more comprehensive and comprehensive research in Indonesia.

\subsection{RESEARCH METHODOLOGY}

\subsection{Research Strategies}

The object of research is the household. Sumedang Regency with 26 subdistricts, 283 villages, in 2017 had 370,375 families or households [25]. Not all household populations are respondents. The number of samples is not calculated based on the Slovin formula. To find out population behavior in the use of renewable energy, multistage sampling is used. 5 districts were selected according to their respective characteristics. For every 1,000 households in each sub-district, 1 household was randomly selected as a respondent (systematic random sampling). For the calculation of the use of renewable primary energy in Sumedang will be calculated based on secondary data obtained from various sources and results of research on population behavior. For national scale calculations, will be determined based on achievements in Sumedang.

\subsection{Research Sites and Samples}

The study sites were conducted in several villages as shown in Table 2.1 below.

Table 2.1: Research Sites and Samples

\begin{tabular}{|c|c|c|c|c|}
\hline Selected Subdistric & $\begin{array}{c}\text { Number of } \\
\text { Family }\end{array}$ & $\begin{array}{c}\text { Total } \\
\text { Number of }\end{array}$ & Selected Village & $\begin{array}{c}\text { Number of } \\
\text { Samples }\end{array}$ \\
\hline
\end{tabular}

\begin{tabular}{|c|c|c|c|c|}
\hline & Heads & Samples & & \\
\hline Tanjungsari & 23.356 & 23 & Tanjungsari & 23 \\
\hline \multirow{2}{*}{ Pamulihan } & \multirow{2}{*}{20.036} & \multirow{2}{*}{20} & Haurngombong & 11 \\
\hline & & & Pamulihan & 9 \\
\hline $\begin{array}{c}\text { Sumedang } \\
\text { Utara }\end{array}$ & 30.003 & 30 & Kebonjati & 30 \\
\hline Cibugel & 7.438 & 7 & Tamansari & 7 \\
\hline Surian & 4.479 & 4 & Surian & 4 \\
\hline Total & & 84 & & 84 \\
\hline
\end{tabular}

Tanjungsari Village, Tanjungsari Subdistrict is a village whose population mostly use LPG for household or business purposes [24]. Haurngombong Village, Pamulihan Subdistrict is the first Energy Independent Village (DME) and became a pilot DME in Sumedang [16]. However, according to data from the Sumedang Regional Government [24], the majority of the population uses LPG. Pamulihan Village, Pamulihan Subdistrict is a village where most of the population uses firewood for household and business purposes. Kebonjati Village, North Sumedang Subdistrict is a village whose population mostly use LPG [24]. But the results of observations on the first visit at the center of tofu craftsmen in Kebonjati on October 27, 2018, there were 9 tofu craftsmen who used rice husks. Tamansari Village, Cibugel Subdistrict is a village where most of the population uses kerosene [25]. Surian Village, Surian Subdistrict is one of nine villages where the majority of the population uses firewood.

\subsection{Types and Data Sources}

The type of data used in this study are primary and secondary data. Primary data obtained from survey results. Secondary data were obtained from several sources both through direct visits and from websites $[1,14,15,16,18,25,26]$.

\subsection{Survey Implementation}

The survey was conducted by means of qualitative interviews through face-to-face or filling out survey forms online.

\subsection{Primary Data Collection in Sumedang}

The population survey was conducted face-to-face and online. Online system is prepared using free facilities from Google Forms: Free Online Surveys for Personal Use. Data collected through a face-to-face survey was entered into Google Forms, https://goo.gl/forms/BmZnHElcvuUVchpN2 uploaded since 6 December 2018. The face-to-face survey was conducted on 16 December 2018, 17 December 2018, 18 December 2018, 23 December 2018 and 30 December 2018. Realization of 85 faceto-face samples, 16 online, totaling 101 exceeding the initial target of 84 as shown in Table 2.2.

Table 2.2: Realization of Research Sites and Samples

\begin{tabular}{|c|c|c|c|c|}
\hline \multirow[b]{2}{*}{ Selected Subdistrics } & \multirow[b]{2}{*}{$\begin{array}{l}\text { Surveyed } \\
\text { Village }\end{array}$} & \multicolumn{3}{|c|}{ Number of Realized Samples } \\
\hline & & $\begin{array}{l}\text { Face to } \\
\text { Face }\end{array}$ & $\begin{array}{l}\text { On- } \\
\text { line }\end{array}$ & Total \\
\hline \multirow{2}{*}{ Tanjungsari } & Tanjungsari & 18 & - & 18 \\
\hline & Marga Jaya & 5 & - & 5 \\
\hline \multirow{4}{*}{ Pamulihan } & Haurngombong & 11 & - & 11 \\
\hline & Pamulihan & - & - & 0 \\
\hline & Mekarbakti & 2 & - & 2 \\
\hline & Cilembu & 8 & - & 8 \\
\hline
\end{tabular}




\begin{tabular}{|l|l|r|r|r|}
\hline \multirow{4}{*}{ Sumedang Utara } & Kebonjati & 28 & 8 & 36 \\
\cline { 2 - 5 } & Situ & - & 2 & 2 \\
\cline { 2 - 5 } & Girimukti & - & 1 & 1 \\
\cline { 2 - 5 } & Rancamulya & - & 1 & 1 \\
\cline { 2 - 5 } & Kotakaler & - & 1 & 1 \\
\hline \multirow{2}{*}{ Cibugel } & Tamansari & 8 & - & 8 \\
\cline { 2 - 5 } & Cibugel & 1 & - & 1 \\
\hline Surian & Surian & 4 & - & 4 \\
\hline Sumedang Selatan & Kotakulon & - & 1 & $1-$ \\
\cline { 2 - 5 } & Rancapurut & - & 1 & 1 \\
\hline Tanjungkerta & Tanjungmekar & - & 1 & 1 \\
\hline Total & & 85 & 16 & 101 \\
\hline
\end{tabular}

\subsection{Primary Data Collection in Indonesia}

The population survey was conducted online and in person. Online system is prepared using free facilities from Google Forms: Free Online Surveys for Personal Use. Data collected through a face-to-face survey was entered into Google Forms, https://goo.gl/forms/XP2gnZDKHJ8 bjkpX2 uploaded since 6 December 2018 and closed on 20 January 2019. The face-to-face survey was conducted in Pontianak City, Pontianak West Kalimantan; Bogor Regency; Bandung district; Brebes Regency; Kebumen Regency; Pekalongan Regency; Cilacap Regency in the period from December 15, 2018 to January 15, 2019. Realized online samples were 420, and face to face including those in Sumedang were 154 , bringing the total to 574 as shown in Table 2.3.

\begin{tabular}{|c|c|c|c|c|c|c|}
\hline \multirow[b]{2}{*}{ Province } & \multirow{2}{*}{$\mid \begin{array}{c}\text { No. of } \\
\text { Regencies/ } \\
\text { Cities }\end{array}$} & \multirow{2}{*}{$\begin{array}{c}\text { No. of } \\
\text { Subdistricts }\end{array}$} & \multirow{2}{*}{$\begin{array}{l}\text { No. of } \\
\text { Villages }\end{array}$} & \multicolumn{3}{|c|}{$\begin{array}{c}\text { Number of } \\
\text { Realized Samples }\end{array}$} \\
\hline & & & & $\begin{array}{l}\text { On- } \\
\text { line }\end{array}$ & \begin{tabular}{|c|} 
Face \\
to \\
Face
\end{tabular} & Total \\
\hline Jawa Barat & 16 & 62 & 78 & 98 & 115 & 213 \\
\hline DKI Jakarta & 5 & 28 & 47 & 60 & 1 & 61 \\
\hline Banten & 8 & 19 & 30 & 27 & 9 & 36 \\
\hline Jawa Tengah & 11 & 15 & 15 & 13 & 12 & 25 \\
\hline DI Yogyakarta & 2 & 5 & 5 & 5 & - & 5 \\
\hline Jawa Timur & 16 & 44 & 53 & 63 & - & 63 \\
\hline Kalimantan Barat & 1 & 4 & 8 & 7 & 17 & 24 \\
\hline Kalimantan Selatan & 5 & 16 & 26 & 45 & - & 45 \\
\hline Kalimantan Timur & 3 & 4 & 4 & 4 & - & 4 \\
\hline Kepulauan Riau & 1 & 7 & 17 & 33 & - & 33 \\
\hline Riau & 1 & 3 & 6 & 6 & - & 6 \\
\hline Sumatera Barat & 2 & 3 & 3 & 4 & - & 4 \\
\hline Sumatera Selatan & 1 & 2 & 2 & 2 & - & 2 \\
\hline Lampung & 2 & 5 & 6 & 6 & - & 6 \\
\hline Sulawesi Selatan & 2 & 3 & 4 & 8 & - & 8 \\
\hline Sulawesi Tenggara & 2 & 2 & 2 & 2 & - & 2 \\
\hline Sulawesi Barat & 1 & 1 & 1 & 1 & - & 1 \\
\hline Nusa Tenggara Barat & 5 & 10 & 15 & 16 & - & 16 \\
\hline Papua Barat & 2 & 2 & 2 & 2 & - & 2 \\
\hline Maluku Utara & 3 & 3 & 4 & 4 & - & 4 \\
\hline Nusa Tenggara Timur & 1 & 1 & 1 & 1 & - & 1 \\
\hline Bali & 1 & 1 & 1 & 1 & - & 1 \\
\hline Empty & - & - & - & 12 & - & 12 \\
\hline $22 / 34(64,7 \%)$ & $\begin{array}{c}91 / 514 \\
(17,7 \%)\end{array}$ & $\begin{array}{c}240 / 7.201 \\
(3,33 \%)\end{array}$ & $\begin{array}{c}366 / 83.447 \\
(0,44 \%)\end{array}$ & & & \\
\hline Total & & & & 420 & 154 & 574 \\
\hline
\end{tabular}

2.5 Secondary Data Collection in Sumedang

\subsubsection{Tofu Craftsman Data}

According to data from the Sumedang Regency Industry Office in 2017, there were 282 tofu craftsmen [27]. Table 2.4 presents a simplification of the data which is adjusted to the needs of this study.

Table 2.4: Tofu Craftsmen in Sumedang in 2017

\begin{tabular}{|c|c|c|c|}
\hline $\begin{array}{c}\text { No. of } \\
\text { Craftsmen }\end{array}$ & $\begin{array}{c}\text { No. of } \\
\text { Subdistricts }\end{array}$ & $\begin{array}{c}\text { Production Capacity } \\
\text { (kg/month) }\end{array}$ & $\begin{array}{c}\text { Total Capacity } \\
\text { (kg/month) }\end{array}$ \\
\hline 282 & 22 & $\begin{array}{c}1.200 \\
\text { s/d } 900.000\end{array}$ & 12.781 .704 \\
\hline
\end{tabular}

\subsubsection{Cattle Breeder Data}

Cattle population in 2017 in Sumedang Regency according to BPS Catalog: 1102001.3211 [25] as shown in Table 2.5.

Table 2.5: Cattle Population in Sumedang Regency

\begin{tabular}{|c|c|c|c|}
\hline $\begin{array}{c}\text { Tyoe of } \\
\text { Cattle }\end{array}$ & $\begin{array}{c}\text { No. of } \\
\text { Subdistricts }\end{array}$ & $\begin{array}{c}\text { No. of Cattles } \\
\text { (Tails) }\end{array}$ & $\begin{array}{c}\text { Potential for Cattle's } \\
\text { Manure (kg/day) }{ }^{\text {(a) }}\end{array}$ \\
\hline Dairy & 12 & 4.163 & 114.182 \\
\hline Beef & 25 & 29.592 & 813.780 \\
\hline & Total & 33.755 & 928.262 \\
\hline
\end{tabular}

Note: (a) A cattle can produce $25-30 \mathrm{~kg}$ of manure/day. In the calculation used $27.5 \mathrm{~kg} / \mathrm{day}$.

\subsubsection{Population Growth Data}

Population and family growth in Sumedang Regency is shown in Table 2.6. and Table 2.7.

Table 2.6: Sumedang Regency Population Growth Data 2018-

\begin{tabular}{|c|c|c|c|c|c|c|c|c|}
\hline \multicolumn{9}{|c|}{2025} \\
\hline 2017 & 2018 & 2019 & 2020 & 2021 & 2022 & 2023 & 2024 & 2025 \\
\hline$\cong$ & $\bar{\Omega}$ & ర్ & $n$ & 8 & $\infty$ & กิ & $\infty$ & 点 \\
\hline$\stackrel{0}{0}$ & $\stackrel{\circ}{\circ}$ & $\stackrel{n}{n}$ & iิ & రిర్ర & $\stackrel{\circ}{\circ}$ & $\stackrel{i}{I}$ & 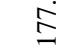 & $\dot{\infty}$ \\
\hline ـ & - & $-\dot{ }$ & - & - & $-\dot{-}$ & $-\dot{ }$ & $-\dot{-}$ & $-\dot{ }$ \\
\hline
\end{tabular}

Source: $\quad$ BPS Catalog:1102001.3211, Sumedang Regency in Figures 2018, Sumedang Regency Central Statistics Agency [25]

Table 2.7: Sumedang Regency Family Growth Data 2018-2025

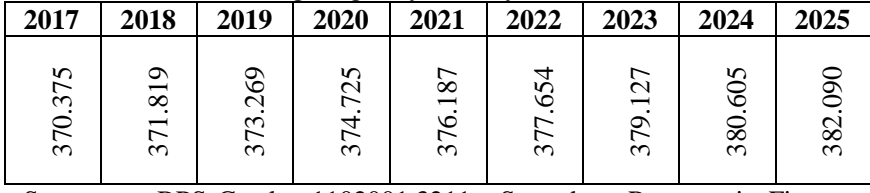

Source: $\quad$ BPS Catalog:1102001.3211, Sumedang Regency in Figures 2018, Sumedang Regency Central Statistics Agency [25]

\subsection{Secondary Data Collection in Indonesia}

\subsubsection{Tofu Craftmen Data}

According to the Ministry of Agriculture's 2017 Horticultural Food Outlook, soybean balance projections in Indonesia 20182021 [28], Indonesia imported more than 2 million tons of soybeans since 2018. BPS data in 2017 [29] shows higher soybean import figures than projected Ministry of Agriculture. Table 2.8 uses processed BPS data, where $70 \%$ of imported soybeans [30] are absorbed by tofu and tempeh craftsmen and it is assumed that $60 \%$ is utilized by tofu craftsmen. 
Table 2.8: Production Capacity of Tofu Craftsmen in Indonesia in 2017

\begin{tabular}{|c|c|}
\hline $\begin{array}{c}\text { Import } \\
\text { (ton/year) }\end{array}$ & $\begin{array}{c}\text { Production Capacity } \\
\text { (ton/year) }\end{array}$ \\
\hline $2.671 .914,1$ & $1.122 .203,9$ \\
\hline
\end{tabular}

\subsubsection{Cattle Breeder Data}

2018 cattle population in Indonesia according to BPS Catalog: 1101001 Statistics Indonesia 2019 [30] and http://www.bps.go.id/linkTableDinamis/view/id/1016 [31] as shown in Table 2.9 .

Table 2.9: Cattles Population in Indonesia

\begin{tabular}{|c|c|c|c|}
\hline $\begin{array}{c}\text { Type of } \\
\text { Cattles }\end{array}$ & $\begin{array}{c}\text { No. of } \\
\text { Province }\end{array}$ & $\begin{array}{c}\text { No. of Cattles } \\
\text { (Tails) }\end{array}$ & $\begin{array}{c}\text { Minimal Potential of Cattle's } \\
\text { Manure (kg/day) }{ }^{\text {(a) }}\end{array}$ \\
\hline Dairy & 18 & 550.100 & $15,13 \times 10^{6}$ \\
\hline Beef & 34 & 17.050 .000 & $468,9 \times 10^{6}$ \\
\hline & Total & 17.600 .100 & $484,03 \times 10^{6}$ \\
\hline
\end{tabular}

Note: (a) A cattle can produce $25-30 \mathrm{~kg}$ of manure/day. In the calculation used $27.5 \mathrm{~kg} / \mathrm{day}$.

\subsubsection{Population Growth Data}

Population and family growth in Indonesia is shown in Table 2.10. and Table 2.11 .

Table 2.10: Indonesian Population Growth Data 2018-2025 (in million)

\begin{tabular}{l|c|c|c|c|c|c|c|c|}
\hline $\mathbf{2 0 1 7}$ & $\mathbf{2 0 1 8}$ & $\mathbf{2 0 1 9}$ & $\mathbf{2 0 2 0}$ & $\mathbf{2 0 2 1}$ & $\mathbf{2 0 2 2}$ & $\mathbf{2 0 2 3}$ & $\mathbf{2 0 2 4}$ & $\mathbf{2 0 2 5}$ \\
\hline 261,7 & 264,8 & 267,9 & 271,1 & 273,8 & 276,6 & 279,3 & 282,1 & 284.8 \\
\hline
\end{tabular}
Source: Processed from BPS Catalog data: 2101018 Indonesian
Population Projection 2010-2035, Agency National Development
Planning, Central Statistics Agency, United Nations Population Fund,
Jakarta 2013 [32]

Table 2.11: Indonesian Family Growth Data 2018-2025 (in million)

\begin{tabular}{|c|c|c|c|c|c|c|c|c|}
\hline $\mathbf{2 0 1 7}$ & $\mathbf{2 0 1 8}$ & $\mathbf{2 0 1 9}$ & $\mathbf{2 0 2 0}$ & $\mathbf{2 0 2 1}$ & $\mathbf{2 0 2 2}$ & $\mathbf{2 0 2 3}$ & $\mathbf{2 0 2 4}$ & $\mathbf{2 0 2 5}$ \\
\hline 67.1 & 67.9 & 68.7 & 69.5 & 70.2 & 70.9 & 71.6 & 72.3 & 73.0 \\
\hline
\end{tabular}

Source: Processed from BPS Catalog data: 2101018 Indonesian Population Projection 2010-2035, Agency National Development Planning, Central Statistics Agency, United Nations Population Fund, Jakarta 2013 [32]

Table 2.12: Data on Percentage of Households Using Wood Fuel and Charcoal/Briquettes

\begin{tabular}{|l|c|c|c|c|c|c|}
\hline \multicolumn{1}{|c|}{ Year } & \multicolumn{2}{|c|}{2015} & \multicolumn{2}{|c|}{2016} & \multicolumn{2}{c|}{2018} \\
\hline The Region & Firewood & $\begin{array}{l}\text { Charcoal/ } \\
\text { Briquettes }\end{array}$ & Firewood & $\begin{array}{c}\text { Charcoal// } \\
\text { Briquettes }\end{array}$ & Firewood & $\begin{array}{c}\text { Charcoal/ } \\
\text { Briquettes }\end{array}$ \\
\hline Jawa Barat & $\mathbf{1 5 , 7 1}$ & $\mathbf{0 , 0 1}$ & $\mathbf{1 3 , 8 0}$ & $\mathbf{0 , 0 4}$ & $\mathbf{1 0 , 9 8}$ & $\mathbf{0 , 0 0}$ \\
\hline $\begin{array}{l}\text { Sumatera } \\
\text { Barat }\end{array}$ & 40,34 & 0,03 & 34,53 & 0,03 & 24,48 & 0,00 \\
\hline $\begin{array}{l}\text { Kepulauan } \\
\text { Riau }\end{array}$ & 3,72 & 0,09 & 2,77 & 0,02 & 2,63 & 0,05 \\
\hline $\begin{array}{l}\text { DI } \\
\text { Yogyakarta }\end{array}$ & 27,49 & 0,29 & 26,16 & 0,26 & 19,77 & 0,29 \\
\hline $\begin{array}{l}\text { DKI } \\
\text { Jakarta }\end{array}$ & 0,05 & 0,00 & 0,05 & 0,00 & 0,02 & 0,00 \\
\hline $\begin{array}{l}\text { Nusa Tenggara } \\
\text { Timur }\end{array}$ & 78,17 & 0,00 & 77,58 & 0,06 & 74,81 & 0,00 \\
\hline $\begin{array}{l}\text { Bali } \\
\text { Bali }\end{array}$ & 26,35 & 0,00 & 23,59 & 0,00 & 18,63 & 0,00 \\
\hline $\begin{array}{l}\text { Kalimantan } \\
\text { Tengah }\end{array}$ & 30,40 & 0,04 & 25,19 & 0,02 & 15,69 & 0,00 \\
\hline
\end{tabular}

\begin{tabular}{|l|c|c|c|c|c|c|}
\hline $\begin{array}{l}\text { Kalimantan } \\
\text { Timur }\end{array}$ & 4,89 & 0,30 & 3,10 & 0,27 & 3,01 & 0,08 \\
\hline $\begin{array}{l}\text { Sulawesi } \\
\text { Tengah }\end{array}$ & 56,43 & 5,41 & 50,73 & 4,41 & 36,09 & 1,56 \\
\hline $\begin{array}{l}\text { Sulawesi } \\
\text { Selatan }\end{array}$ & 18,98 & 0,84 & 15,56 & 0,51 & 11,61 & 0,43 \\
\hline Papua & 67,74 & 0,10 & 67,04 & 0,14 & 64,37 & 0,04 \\
\hline Papua Barat & 35,55 & 0,10 & 39,01 & 0,31 & 27,16 & 0,00 \\
\hline Indonesia & $\mathbf{2 4 , 4 0}$ & $\mathbf{0 , 2 4}$ & $\mathbf{2 1 , 5 7}$ & $\mathbf{0 , 1 9}$ & $\mathbf{1 6 , 4 0}$ & $\mathbf{0 , 0 9}$ \\
\hline
\end{tabular}

Source: Processed from BPS data, Percentage of Households by Province and Fuel Main for Cooking in 2001, 2007-2016 and 2018 [15,17].

\subsection{DISCUSSION}

1. From the results of logistic regression analysis in Sumedang, there is a decrease in the use of solid fuels and LPG in 2025 as shown in Figure 3.1. However, the use of biogas, experienced a very significant increase in 2025 .

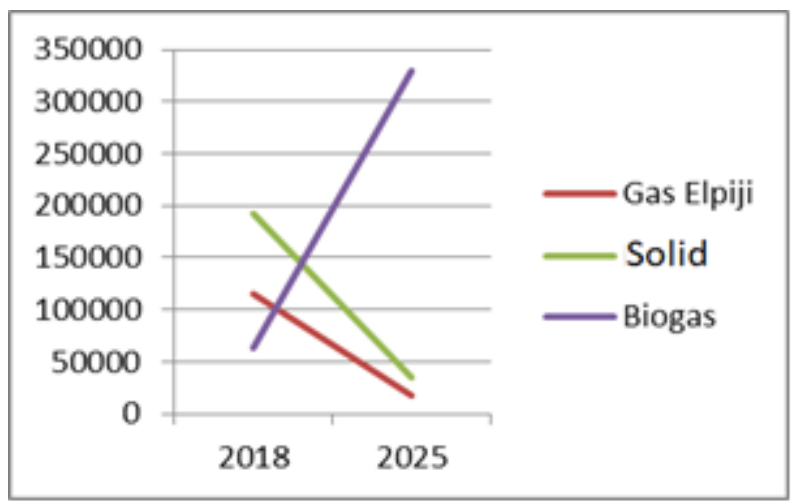

Figure 3.1: Results of Logistic Regression Analysis

2. The potential contribution of the Sumedang population to the achievement of the primary renewable energy mix can be seen in Table 3.1.

Table 3.1: Potential Population Contribution to Achievement of Primary Energy Mix Renewable Energy in Sumedang

\begin{tabular}{|c|c|c|}
\hline Fuel & $\mathbf{2 0 1 8}$ & $\mathbf{2 0 2 5}$ \\
\hline Solid & $0,29 \%$ & $0,23 \%$ \\
\hline Cattle Dung Biogas & $0,00089 \%$ & $0,0037 \%$ \\
\hline Total & $0,291 \%$ & $0,234 \%$ \\
\hline
\end{tabular}

3. From Table 3.1, for a national scale with a total of 514 regencies/cities, the potential contribution of the population can be calculated using the following assumption approach:

Table 3.2: Potential Contributions of Indonesia's Population to the Renewable Energy Mix

\begin{tabular}{|c|c|c|c|}
\hline Region & $\begin{array}{c}\text { No. of } \\
\text { Regencies/Cities }\end{array}$ & $\mathbf{2 0 1 8}$ & $\mathbf{2 0 2 5}$ \\
\hline Sumedang & 1 & $0,291 \%$ & $0,234 \%$ \\
\hline $\begin{array}{c}2 \% \text { No. of } \\
\text { Regencies/Cities }\end{array}$ & 10 & $2,91 \%$ & $2,34 \%$ \\
\hline $\begin{array}{c}5 \% \text { No. Of } \\
\text { Regencies/Cities }\end{array}$ & 26 & $7,57 \%$ & $6,08 \%$ \\
\hline $7 \%$ No. Of & 36 & $10,48 \%$ & $8,42 \%$ \\
\hline
\end{tabular}




\begin{tabular}{|c|c|c|c|}
\hline Regencies/Cities & & & \\
\hline $\begin{array}{c}10 \% \text { No. of } \\
\text { Regencies/Cities }\end{array}$ & 51 & $14,84 \%$ & $11,93 \%$ \\
\hline
\end{tabular}

4. Different from Sumedang, the results of logistic regression analysis in Indonesia, there is an increase very significantly in the use of solid fuels and decrease in LPG in 2025 as shown in Figure 3.2. However, the increase in the use of biogas is not that significant in 2025.

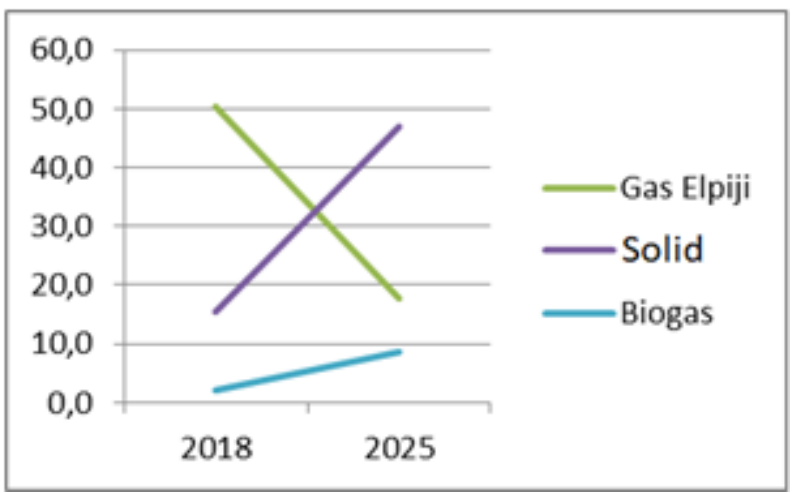

Figure 3.2: Results of Logistic Regression Analysis

5. The potential population contribution to the achievement of the primary renewable energy mix in Indonesia can be seen in Table 3.3.

Table 3.3: Potential Population Contribution to the Achievement of the Primary Renewable Energy Mix in Indonesia

\begin{tabular}{|c|c|c|}
\hline Fuel & 2018 & 2025 \\
\hline Solid & $3,33 \%$ & $6,81 \%$ \\
\hline Cattle Dung Biogas & $0,47 \%$ & $1,35 \%$ \\
\hline Total & $3,80 \%$ & $8,16 \%$ \\
\hline
\end{tabular}

\subsection{CONCLUSIONS AND RECOMMENDATION}

\subsection{Conclusions}

Based on the results of research and discussion in Section 3.0, the following conclusions can be drawn:

1. 7.9 (seven point nine) percent of respondents in Sumedang only use firewood on a daily basis for household needs. 25.7 (twenty five point seven) percent who use firewood and $3 \mathrm{~kg}$ LPG. 2 (two) percent use firewood, tofu biogas waste and 3 kg LPG. 4 (four) percent who use rice husk (bran), biogas waste tofu and $3 \mathrm{~kg} \mathrm{LPG.} 2$ (two) percent use rice husk (bran), biogas from tofu waste and $12 \mathrm{~kg} \mathrm{LPG} 14.9$ (fourteen point nine) percent use tofu waste biogas and $3 \mathrm{~kg}$ LPG. 22.8 (twenty two point eight) percent use $3 \mathrm{~kg}$ LPG. 5 (five) percent use $12 \mathrm{~kg}$ LPG. Total RE use is more than 56.5 (fifty six point five) percent.

50 (fifty) percent of respondents said they used firewood because it was easy to get, free / available around the house / garden / forest. 84.6 (eighty four point six) percent of respondents have used firewood for more than 16 (sixteen) years.
Thus, hypothesis 2.5.a) "More than 40 (forty) percent of households in villages and 10 (ten) percent in cities cook using firewood or rice husks or sawdust or other solid fuels" can be said to be fulfilled.

2. 92.6 (ninety-two point six) percent of respondents know tofu craftsmen using solid fuel and its combination with biogas / LPG. Hypothesis 2.5.b) "More than 80 (eighty) percent of tofu craftsmen use fuel wood fuel or rice husk or other solid fuels" can be said to be fulfilled.

3. 11.1 (eleven point one) percent of respondents of dairy farmers who utilize dairy cow dung to be used as biogas. Hypothesis 2.5.c) "More than 80 (eighty) percent of dairy farmers use their manure for biogas" not fulfilled.

4. There are no respondents who work as beef cattle breeders and other animals, hypothesis 2.5.d) "No more than 5 (five) percent of beef cattle breeders have used their manure to be used as biogas" and e) "No more than 5 (five) percent of other animal farmers and poultry that use their manure for biogas "are not met.

5. 49.9 (forty-nine point nine) percent of respondents know tofu utilizing their liquid waste to be used as biogas. Hypothesis 2.5.f) "No more than 20 (twenty) percent of tofu craftsmen who use their liquid waste to be used as biogas" can be said to be fulfilled.

6. The contribution and potential contribution of the Indonesian population to the achievement of the primary energy mix target for EBT, especially in the use of solid fuels and biogas for household and business needs, should be taken into account by the government.

The minimum contribution that can be achieved is 3.80 (three point eight) percent in 2018 and increased to 8.16 (eight point sixteen) percent in 2025 or around 35 (thirty five) percent of the target mix.

\subsection{Recommendations}

1. The Government, through the National Energy Council, conducts more comprehensive research in all regions in Indonesia to be able to obtain real data. The real data to be obtained is data on the amount of use of solid fuels and biogas as well as the potential that can be generated from the utilization of livestock manure which has not been processed into biogas. This data can be used as material in calculating the achievement of the NRE target that must be achieved by the government, both in 2025 and 2050.

2. Accelerating the planting program of Industrial Energy Forest Plantations (HTIE) by dividing 3 plantation areas:

a. For the purposes of cooking / business of the population.

b. For regional power generation purposes remote / isolated.

c. For export purposes by making firewood in the form of wood pellets or wood chips.

3. Monitor the use of energy efficient furnace equipment and reactor / biogas digesters that have been donated by the government / Dinas ESDM / PLN / other parties to residents or village cooperatives to be maintained and improved by users.

4. Conducting socialization to the rural population on the benefits of using and utilizing solid fuels and biogas from animal waste and tofu waste.

5. Increasing knowledge of farmers and tofu craftsmen on the 
making, installation, operation and maintenance of biogas reactors / digesters.

6. Conduct studies and design innovations and combustion systems waiting for solid fuels with little smoke or smokeless.

7. Conducting studies and innovations in terms of material selection of biogas stoves so that they are not easily corroded.

8. Conduct studies and innovations in making biogas reactors from tofu waste that can be operated simply at a cost that is affordable by tofu craftsmen.

\section{ACKNOWLEDGEMENTS}

The authors would like to convey a great appreciation to all those who help and provide support until the completion of this research.

\section{REFERENCE}

1. Peraturan PresidenRepublik Indonesia Nomor 22 Tahun 2017 Tentang Rencana Umum Energi Nasional, 2 Maret 2017.

2. Peraturan Pemerintah Republik Indonesia Nomor 79 Tahun 2014 Tentang Kebijakan Energi Nasional, 17 Oktober 2014.

3. Peraturan Presiden Republik Indonesia Nomor 61 Tahun 2011 Tentang Kegiatan Rencana Aksi Nasional Penurunan Emisi Gas Rumah Kaca, Lampiran II, 20 September 2011.

4. Pusat Pengkajian Industri Proses dan Energi BPPT, Outlook Energi Indonesia 2018, Energi Berkelanjutan untuk Transportation Darat, ISBN 978-602-1328-05-7, www.bppt.go.id, Agustus 2018.

5. Kementerian Energi dan Sumber Daya Mineral Republik Indonesia, Siaran Pers Nomor: 47/SJI/2015, Menteri ESDM: Integrasi Hulu dan Hilir Industri Bioenergi akan Terwujud, 13 Juli 2015.

6. Harian Kompas, Energi Terbarukan, Target Bauran Energi Diperkirakan Meleset, 20 September 2017.

7. Direktorat Jenderal Energi Baru, Terbarukan dan Konservasi Energi, Statistik EBTKE 2016, Desember 2016.

8. Kementerian Energi dan Sumber Daya Mineral, Direktorat Jenderal Energi Baru Terbarukan dan Konservasi Energi, Regulasi dan Kebijakan Pengembangan Energi Terbarukan, presentasi disampaikan pada FGD Hari Pers Nasional di Padang, 30 Januari 2018.

9. Kementerian Energi dan Sumber Daya Mineral Republik Indonesia, EnergiBerkeadilan, Hasil kerja 2017 dan Semester-I 2018, Version 2.0, Publikasi Juli 2018.

10. Keputusan Menteri Energi dan Sumber Daya Mineral Republik Indonesia Nomor 1567 K/21/MEM/2018 Tentang Pengesahan Rencana Usaha Penyediaan Tenaga Listrik PT Perusahaan Listrik Negara (Persero) Tahun 2018 S.D. 2027, 13 Maret 2018.

11. Peraturan Menteri Energi dan Sumber Daya Mineral Republik Indonesia Nomor 41 Tahun 2018 Tentang Penyediaan dan Pemanfaatan Bahan Bakar Nabati Jenis Biodiesel Dalam Kerangka Pembiayaan Oleh Badan Pengelola Dana Perkebunan Kelapa Sawit, 23 Agustus 2018.

12. Badan Pusat Statistik Provinsi Jawa Barat, Provinsi Jawa
Barat Dalam Angka 2018, Katalog: 1102001.32, Agustus 2018.

13. Badan Pusat Statistik Provinsi Jawa Barat, Statistik Perumahan Provinsi Jawa Barat 2017. Katalog: 3303002.32, September 2018.

14. Syafrina Syaaf, Pengguna kayu bakar untuk memasak masih tinggi di Indonesia, 06 Mei 2018, diakses melalui http://beritagar.id/artikel/gaya-hidup/pengguna-kayu-bakaruntuk-memasak-masih-timggi-di-indonesia.

15. Badan Pusat Statistik, Beranda Lingkungan Hidup, "Persentase Rumah Tangga Menurut Provinsi dan Bahan Bakar Utama Untuk Memasak Tahun 2001, 2007-2016, 14 Nov 2017.

16. Direktorat Jenderal Energi Baru, Terbarukan dan Konservasi Energi, Kementerian Energi dan Sumber Daya Mineral, Buku Statistik EBTKE 2015, Desember 2015.

17. Perhutani, Berita \& Press Release, "Penggunaan Kayu Bakar Terus Meningkat, 2 April 2012," diakses melalui http://www.perhutani.co.id/2012/04/penggunaan-kayubakar-terus-meningkat/.

18. Hasil Pengembangan Biogas Di Provinsi Jawa Barat Tahun 2006-2015.

19. Wiwien Widaningsih, Partisipasi Masyarakat Melalui Desa Mandiri Energi Berbasis Biogas Limbah Ternak Sapi Di Desa Haurngombong Kecamatan Pamulihan Kabupaten Sumedang, Jurnal Ilmu Administrasi, Volume XI, Nomor 1, April 2014.

20. Adang Agustian dan Supena Friyatno, Prospek Pengembangan Biogas Dari Kotoran Ternak Mendukung Sistem Pertanian-Bioindustri Di Provinsi Jawa Barat, Prosiding Seminar Nasional Hari Pangan Sedunia Ke-34: Pertanian-Bioindustri Berbasis Pangan Lokal Potensial, 4 November 2014.

21. Program kerja sama antara Kementerian ESDM-Direktorat Jenderal Energi Baru Terbarukan dan Konservasi EnergiDirektorat bioenergy-dan Bank Dunia-Clean Stove Initiative-dan Yayasan Dian Desa, Program Tungku Sehat Hemat Energi Biomassa (TSHE) - Indonesia, diakses melalui www.tungkuindonesia.org atau www.diandesa.org pada 5/11/2018.

22. Andre R. Daud, Nilai Ekonomi Manfaat Biogas Pada Rumahtangga Peternak Sapi Perah: Survey di Desa Haungombong Kecamatan Pamulihan Kabupaten Sumedang, Sosiohumaniora, Volume 13, No. 3, November 2011: 243250.

23. Kabupaten Sumedang, Profil Daerah, Strategi dan Kebijakan, Kabupaten Sumedang - Website Resmi Pemerintah Provinsi Jawa Barat, diakses melalui http://www1.jabarprov.go.id/index.php/pages/id/1051 pada 8/1/2018.

24. Badan Pusat Statistik, "Statistik Potensi Desa Indonesia 2014," Katalog BPS: 1105014, November 2014, beserta hasil olahan Bappeda Kabupaten Sumedang, 2017.

25. Badan Pusat Statistik Kabupaten Sumedang, Kabupaten Sumedang Dalam Angka 2018, Katalog BPS: 11002001.3211, Agustus 2018.

26. Arsip Berita Media Center ESDM, Biogas Rumah, Olah Limbah Jadi Berkah, 17 Oktober 2018, diakses melalui https://www.esdm.go.id/id/media-center/arsip-berita/biogas- 
rumah-olah-limbah-jadi-berkah pada 10/31/2018.

27. Dinas Perindustrian Sumedang, Direktori Perusahaan IKM Tahu Tahun 2017, diterima melalui email pada 12 November 2018.

28. Pusat Data dan Sistem Informasi Pertanian, Sekretariat Jenderal, Kementerian Pertanian, TA.2017, "Outlook Tanaman Pangan dan Hortikultura 2017”, ISSN: 1907-1507.

29. Badan Pusat Statistik, "Impor Kedelai Manurut Negara Asal Utama, 2010-2017", https://www.bps.go.id/statictable/2019/02/14/2015/imporkedelai-menurut-negara-asal-utama-2010-2017.

30. Badan Pusat Statistik, "Statistik Indonesia 2019", Katalog:1101001.

31. Badan Pusat Statistik, "Populasi Sapi Potong menurut Provinsi, 2009-2018”, https://www.bps.go.id/linkTableDinamis/view/id/1016.

32. Badan Perencanaan Pembangunan Nasional, Badan Pusat Statistik, United Nations Population, "Proyeksi Penduduk Indonesia". 